\title{
Subcutaneous administration of ketoprofen delays Ehrlich solid tumor growth in mice
}

\author{
[Administração subcutânea de cetoprofeno reduz o crescimento do tumor sólido \\ de Ehrlich em camundongos] \\ C.M. Souza ${ }^{1,2}$, P.A. Auler ${ }^{1}$, D.C. Reis ${ }^{1}$, G.E. Lavalle $^{1}$, E. Ferreira ${ }^{1}$, G.D. Cassali ${ }^{1 *}$ \\ ${ }^{1}$ Instituto de Ciências Biológicas - Universidade Federal de Minas Gerais - Belo Horizonte, MG \\ ${ }^{2}$ Fundação Comunitária de Ensino Superior de Itabira - Itabira, MG
}

\begin{abstract}
Ketoprofen, a nonsteroidal anti-inflammatory drug (NSAID) has proven to exert anti-inflammatory, antiproliferative and anti-angiogenic activities in both neoplastic and non-neoplastic conditions. We investigated the effects of this compound on tumor development in Swiss mice previously inoculated with Ehrlich tumor cells. To carry out this study the solid tumor was obtained from cells of the ascites fluid of Ehrlich tumor resuspended in physiological saline to give $2.5 \times 10^{6}$ cells in $0.05 \mathrm{~mL}$. After tumor inoculation, the animals were separated into two groups $(\mathrm{n}=10)$. The animals treated with ketoprofen $0.1 \mu \mathrm{g} / 100 \mu \mathrm{L} / \mathrm{animal}$ were injected intraperitoneally at intervals of $24 \mathrm{~h}$ for 10 consecutive days. Animals from the control group received saline. At the end of the experiment the mice were killed and the tumor removed. We analyzed tumor growth, histomorphological and immunohistochemical characteristics for CDC47 (cellular proliferation marker) and for CD31 (blood vessel marker). Animals treated with the ketoprofen $0.1 \mu \mathrm{g} / 100 \mu \mathrm{L} /$ animal showed lower tumor growth. The treatment did not significantly influence the size of the areas of cancer, inflammation, necrosis and hemorrhage. Moreover, lower rates of tumor cell proliferation were observed in animals treated with ketoprofen compared with the untreated control group. The participation of ketoprofen in controlling tumor malignant cell proliferation would open prospects for its use in clinical and antineoplasic therapy.
\end{abstract}

Keywords: inflammation, cell proliferation, Ketoprofen, neoplasm

\section{RESUMO}

O cetoprofeno é uma droga anti-inflamatória não esteroidal (NSAID), que exerce efeito anti-inflamatório, antiproliferativo e antitumoral em condições neoplásicas e não neoplásicas. Foram investigados os efeitos desse composto sobre o desenvolvimento tumoral de camundongos Swiss previamente inoculados com células do tumor de Ehrlich. Para realização deste estudo, o tumor sólido foi obtido a partir de células do fluido ascítico do tumor de Ehrlich suspendido em solução salina fisiológica para se obter $2,5 \times 10^{6}$ de células em $0,05 \mathrm{~mL}$. Após a inoculação do tumor, os animais foram separados em dois grupos $(n=10)$. Os animais do grupo tratado receberam cetoprofeno 0,1 $\mu \mathrm{g} / 100 \mu \mathrm{L} /$ animal por via intraperitoneal, em intervalos de 24 horas durante 10 dias consecutivos, e o controle $100 \mu \mathrm{L}$ de solução salina. No final do experimento, os animais foram sacrificados, e o tumor removido. Foram analisados o crescimento do tumor e as características histomorfológicas e imunoistoquímicas para CDC47 (marcador de proliferação celular) e para CD31 (marcador de vasos sanguíneos). Os animais tratados com o cetoprofeno 0,1 $\mu \mathrm{g} / 100 \mu \mathrm{L} /$ animal apresentaram menor crescimento do tumor. O tratamento não influenciou significativamente o tamanho das áreas de neoplasia, inflamação, necrose e hemorragia. Em contraste, uma menor taxa de proliferação das células neoplásicas foi observada nos animais tratados com cetoprofeno em comparação com o grupo controle. A participação do cetoprofeno em controlar a proliferação de células neoplásicas abre perspectivas para sua utilização em terapia clínica antineoplásica.

Palavras-chave: inflamação, proliferação celular, cetoprofeno, neoplasia

Recebido em 4 de abril de 2013

Aceito em 19 de fevereiro de 2014

*Autor para correspondência (corresponding author)

E-mail: cassalig@icb.ufmg.br 


\section{INTRODUCTION}

Nonsteroidal anti-inflammatory drugs (NSAID) have an anti-inflammatory effect primarily because they bind with the isoform of the cyclooxygenase (COX) enzymes and may act on cancer development through the COX (Bosco et al., 2011).

Some studies indicate that the use of COX inhibitors is a major form of therapy in the treatment of human tumors in vitro and in vivo (O'Brien et al., 2011; Zerbini et al., 2011; Hossain et al., 2011). In breast oncology, recent studies demonstrate the therapeutic effects of these compounds as preventive agents and/or for chemotherapy, but data are conflicting (O'Brien et al., 2011; Bosco et al., 2011; Li et al., 2012).

The cyclooxygenase enzymes are essential for the synthesis of prostaglandins from arachidonic acid by the cell membrane phospholipases. These enzymes are found in two different isoforms and the like which are the type cyclooxygenase 1 (COX-1), constitutively expressed in most cells and tissues, and cyclooxygenase type 2 (COX2)-induced inflammation and interleukin (Gilman et al., 2003; Rang et al., 2004; Ramos et al., 2010; Bosco et al., 2011).

Among the various anti-inflammatory drugs studied recently it is found that ketoprofen, a nonsteroidal anti-inflammatory drug (NSAID) for non-selective COX (Cheng et al., 2006; Kamei et al., 2008; Nakamura et al., 2009), their mechanisms of action include blocking the formation of prostaglandins, thromboxanes and leukotrienes, thereby providing inhibition of vascular responses and cellular inflammation, and also antagonizes the action of bradicidina, and thus, stabilizes cell membranes (Sanchez and Moreno, 1999; Nakamura et al., 2009; Ramos et al., 2010).

Previous studies also showed the effect of ketoprofen in tumorigenesis and apoptosis associated with the tumor, by inhibiting cyclooxygenase, being a therapeutic and/or chemopreventive option (Rao et al., 1996; Kamei et al., 2008).

In experimental oncology the use of ketoprofen was effective to control colon tumor cells in vitro model and in vivo (Wargovich et al., 2000;
Cheng et al., 2006). In nude mice, ketoprofen was effective in reducing tumor growth and lung metastases of osteosarcoma cells (Kamei et al., 2008).

The study of neoplasm in animal models facilitates the evaluation and better understanding of tumor biology, while constituting the evaluation of the effects of certain drugs and/or substances on the neoplastic development. The Ehrlich tumor is primarily a mouse mammary adenocarcinoma in females (Paul Ehrlich, 1906) and, even undifferentiated, it is possible suffer the influences of antiinflammatory drugs in genesis of mammary cancer, and non steroidal anti-inflammatory drugs. However, research on the influence of ketoprofen on tumor growth and the mechanisms involved still have gaps to be clarified. Given the above, this study aims to evaluate the effect of anti-inflammatory ketoprofen in the development of the solid tumor of Ehrlich.

\section{MATERIAL AND METHODS}

Twenty female Swiss mice (6-7 weeks, $30 \mathrm{~g}$ weight) were provided by the Central Animal Facility - Institute of Biological SciencesFederal University of Minas Gerais, Belo Horizonte-Brazil. The animals were housed in groups of four provided with chow pellets and water ad libitum. The light/dark cycle was $12 \mathrm{~h}$ with lights on at 7:00 am and lights off at 7:00pm. Efforts were made to avoid all unnecessary distress to the animals. Housing, anesthesia and care adhered to the guidelines established by our local Institutional Animal Welfare Committee. All procedures performed in this work were approved by the ethics committee for animal experimentation.

The animals were inoculated in the plantar cushion of the left posterior hind limb with an injection $(50 \mu \mathrm{L})$ containing $2.5 \times 10^{6}$ of Ehrlich tumor cells taken from ascites from Swiss mice. The mice were assigned into two groups of 10 animals each and the treatment started post tumor cell inoculation, as follows: Control Group: received saline $0.9 \% \quad(100 \mu \mathrm{L})$; ketoprofen group was treated with intraperitoneal daily doses of ketoprofen $(01 \mu \mathrm{g} / 100 \mu \mathrm{L} / \mathrm{animal})$. The chosen dose of ketoprofen was based on preliminary studies performed in our group 
(unpublished data) that demonstrated that $01 \mu \mathrm{g} / 100 \mu \mathrm{L} / \mathrm{animal}$ is an effective dosage.

During the whole experimental period tumor growth, body weight, water and food ingestion were determined. Tumor growth was assessed with the use of a micrometer (Mitutoyo, measurement $0.01 \mathrm{~mm}$, series number 7301 ) performed before tumor cell inoculation and every day after that.

The animals from each group and their respective controls were killed $24 \mathrm{~h}$ after the last dose of the treatment or vehicle. Necropsies were performed and tumors were removed for histopathological analysis.

Tissues were fixed in formalin $(10 \% \mathrm{w} / \mathrm{v}$ in phosphate-buffered saline - PBS $\mathrm{pH}$ 7.4) and sections $(4 \mu \mathrm{m})$ were stained with hematoxylin and eosin (HE) and processed for lightmicroscopic studies. All staining was performed in paraffin-embedded sections mounted in glass slides. To perform morphometric analysis, images of cross sections obtained from 15 fields per slide $\left(8.533 \mu \mathrm{m}^{2} /\right.$ field $)$ were obtained with a planapochromatic objective $40 \mathrm{x}$ in light microscopy (final magnification $=1000 \mathrm{X}$ ). The images were digitized through a JVC TK$1270 / \mathrm{JGB}$ micro-camera and transferred to an analyzer (Kontron Eletronics, Carl Zeiss KS300 version 2).

In histological sections of tumor-bearing paw stained with HE the percentage of necrotic area, viable neoplastic tissue and inflammation were determined using a graticule of 25 dots. The images were captured with a microcamera Spot Insigh Color adapted to an Olympus Microscope (BX-40). Image analysis was performed using SPOT $^{\circledR}$ software version 3.4 .5 and Corel DRAW $^{\circledR}$ version 7.468 .

Tumor cell proliferative activity was evaluated by immunohistochemical study using the cell proliferation marker CDC47 - clone 47DC141 (Neomarkers). Histological sections $(4 \mu \mathrm{m})$ were stained by avidin-biotinylated-peroxidase complex (DAKO K0690) in which positive and negative controls were included in each bath. The incubation with the primary antibody
(CDC47; 1:300) lasted for $60 \mathrm{~min}$ and peroxidase activity was revealed using diaminobenzidine (DAB-Dako). The index for this marker was obtained by estimating the percentage of positive cells in 500 tumor cells. The counting was performed in 15 fields with 40x objective and 10x ocular microscopy (Souza et al., 2013).

The immunohistochemical technique was also employed to determine the angiogenic index using anti-CD31 (Clone TLD-3A12 - Fitzgerald). The method described by Maeda et al. (1995), was used to count microvascular density (MVD) in hot spot areas (areas with higher number of blood vessels).

Experimental delineation was totally at random, with two treatments and 10 repetitions per treatment, one repetition per animal. Results are presented as mean \pm SEM. Comparisons between groups were carried out using Student's $t$-test for unpaired data. The statistical program used to analyze the data was GraphPad InStat version 3.0 statistic software. A $P$-value below 0.05 was considered significant.

\section{RESULTS}

During the experimental period a decrease in water intake and body weigh in animals treated with ketoprofen was observed. However, there was no statistical difference regarding ration intake in the animals studied (Tab. 1).

Table 1. Mean and standard deviation of daily individual consumption of water and commercial concentrate and weight gain in the different groups studied

\begin{tabular}{lcc}
\hline Consumption & $\begin{array}{c}\text { Control } \\
\text { Group }\end{array}$ & $\begin{array}{c}\text { Treated } \\
\text { Group }\end{array}$ \\
\hline Water $(\mathrm{mL})$ & $29.78 \pm 5.65$ & $24.4 \pm 3.95^{*}$ \\
$\begin{array}{l}\text { Commercial } \\
\text { concentrate } \\
\text { consumption }\end{array}$ & $20.81 \pm 3.99$ & $20.64 \pm 4.82$ \\
$\begin{array}{l}\text { Weight }(\mathrm{g}) \\
* \text { p }<0.05-\text { Values represent means } \pm \text { SD of } 10 \\
\text { animals in each group. }\end{array}$ & $27.5 \pm 1.47$ & $22.2 \pm 2.03^{*}$ \\
\hline
\end{tabular}

Figure 1 shows the effect of systemic administration of ketoprofen on tumor growth. From day 6 post-tumor cell inoculation the tumor 
was smaller in the treated group. The morphometric analysis of the tumor revealed no statistical difference in of neoplastic, inflammation, necrosis and hemorrhagic areas (Tab. 2).

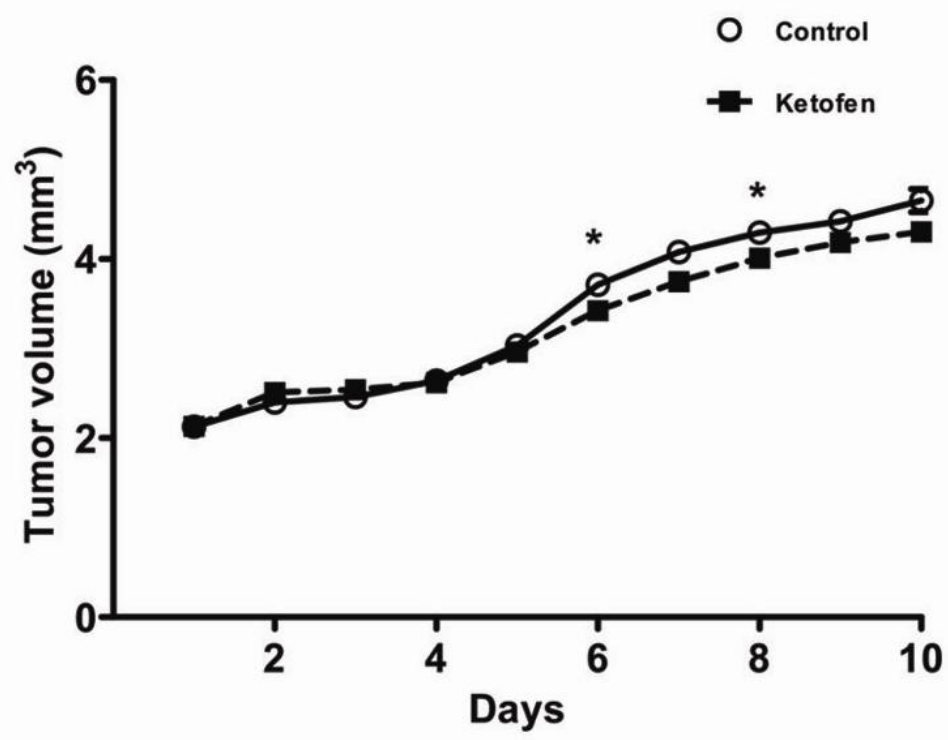

Figure 1. Kinetics of Ehrlich tumor growth and the effects of systemic administration of ketoprofen. Data represent mean $\pm \mathrm{SEM}(* \mathrm{P}>0.05$, $\mathrm{t}$-test $)$ significant difference between the values of control and treated groups.

Table 2. Means and standard deviation of the morphometric variables of solid Ehrlich tumor features in control and treated animals

\begin{tabular}{lcc}
\hline & \multicolumn{2}{c}{ Group } \\
\hline Variables (\%) & Control & Treated \\
\hline Tumor area & $13.42 \pm 2.17$ & $14.41 \pm 3.16^{*}$ \\
Necrosis area & $9.50 \pm 3.78$ & $6.16 \pm 3.65^{*}$ \\
Inflammation area & $1.51 \pm 1.30$ & $5.59 \pm 1.73^{*}$ \\
Hemorrhage area & $0.06 \pm 0.06$ & $0.38 \pm 0.48^{*}$ \\
\hline$*$ P $<0.05$ - Values represent means \pm SD of 10 \\
animals in each group.
\end{tabular}

The number of positive CDC47 tumor cells was decreased in the treated group when compared to their controls (Fig. 2A-C). The microvessel density as determined by counting the number of positive CD31 vessels not was statistically different in the treated group compared with nontreated animals (Fig. 2D-F).

\section{DISCUSSION}

Nonsteroidal antiinflammatory drugs (NSAIDs) seem to reduce the risk of developing cancer.
One mechanism through which NSAIDs act to reduce carcinogenesis is to inhibit the activity of cyclooxygenase-2 (COX-2), an enzyme that is overexpressed in various cancer tissues (Grösch et al., 2006). Thus, the inhibition of these processes has become a potential target in cancer prevention and treatment (O'Brien et al., 2011; Zerbini et al., 2011; Hossain et al., 2011).

Ketoprofen is listed as a drug that would potentially target multiple components of tumor microenvironment (angiogenesis, inflammation, proliferative activity), however, the results of the effects of ketoprofen on a number of clinical and experimental protocols are rather contradictory and/or inconsistent (Marjanovic' et al., 2007; Kamei et al., 2008). Thus, understanding the mechanisms of ketoprofen action may uncover strategies to enhance the efficacy of this important therapeutic agent. In this study we used the Ehrlich tumor to assess the effects of ketoprofen on tumor growth, angiogenic components and proliferative events associated with tumor development. 

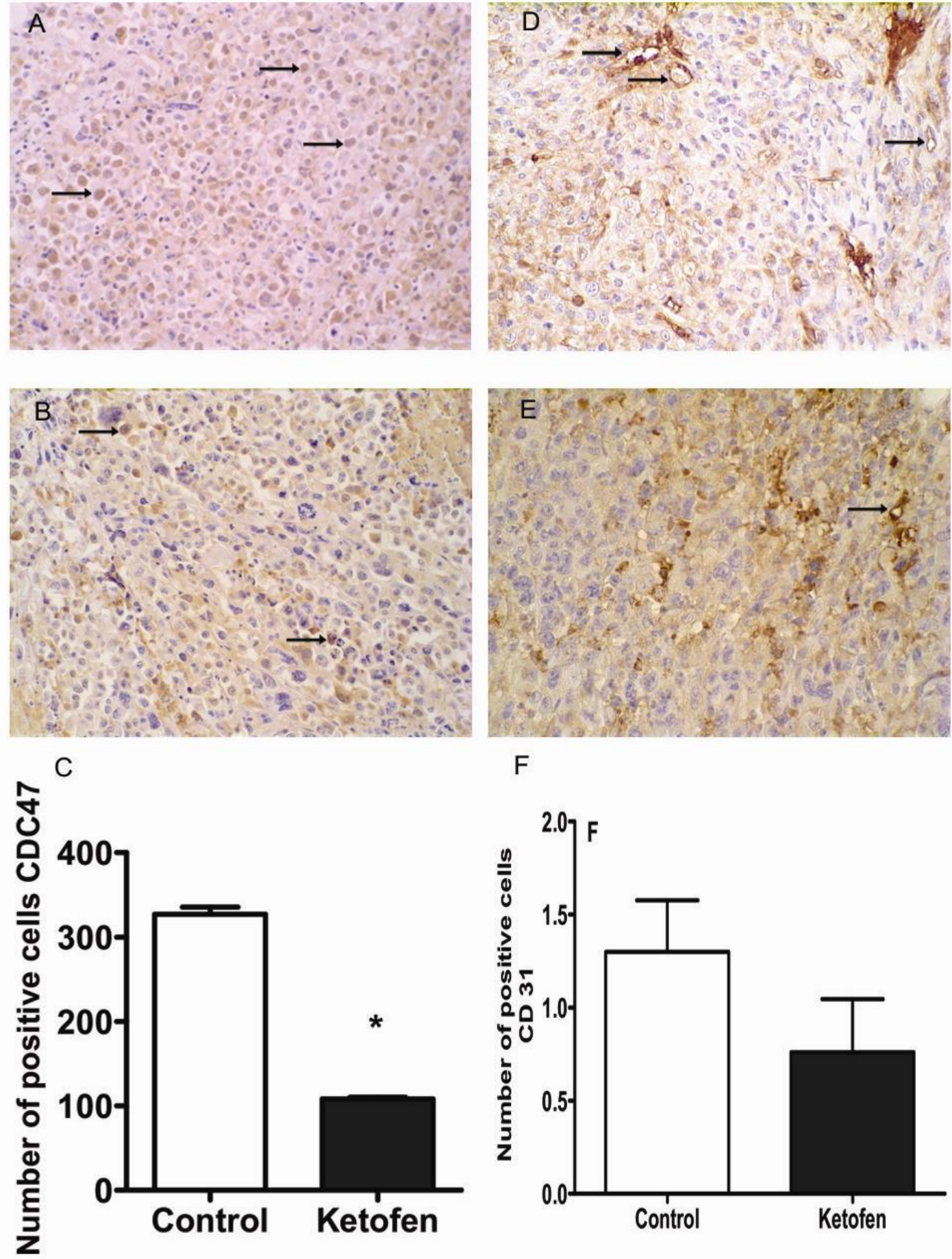

$\mathrm{F}$

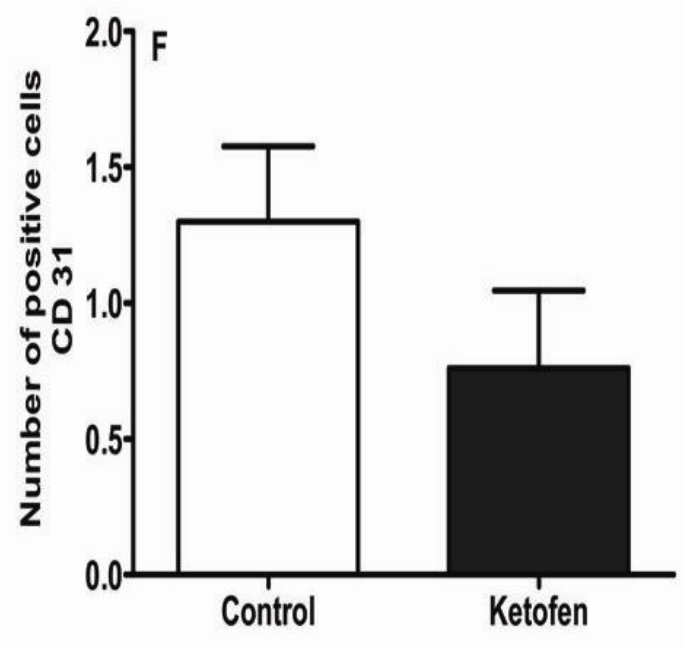

Figure 2. Effects of ketoprofen Ehrlich tumor on cell proliferation and angiogenesis. Representative micrographs of tumor cross sections. In A (control) and B (ketoprofen) immunohistochemical reaction to CDC47/47DC141. Morphometric corenting of positive cells/500 tumor cells is shown in C. In D (control) and $\mathrm{E}$ (ketoprofen) immunohistochemical reaction to CD31/TLD-3A12. Data of blood vessel number in both groups is shown in F. Data represent mean \pm SEM $(* \mathrm{P}>0.05$, t-test) significant difference between the values of control and treated groups. (Arrows) CDC47 and CD31 positive cells. 
In the evaluation of the water intake and body weight, results demonstrated that the ketoprofen was able to significantly reduce these variables in treated animals. Cancer patients often suffer a progressive loss of fat and muscle mass accompanied by profound weakness, anorexia and anemia. This syndrome is called cachexia, resulting from the action of cytokines such as TNF- $\alpha, \quad$ IFN- $\gamma$ released by macrophages (Bachmann et al., 2008; Gueta et al., 2010). Among the possible explanations for the causes of cachexia associated with cancer is the increase of the basal metabolic rate during the illness, which makes it necessary to increase the nutritional intake to meet the new energy requirements.

Systemic administration of ketoprofen $(0.1 \mu \mathrm{g} / 100 \mu \mathrm{L} / \mathrm{animal})$ inhibited tumor growth. Kamei et al. (2008) found that topical administration of $286 \mathrm{mg}$ daily of ketoprofen inhibited tumor growth of osteosarcoma and lung metastases. Marjanovic et al. (2007) showed that the antiproliferative ketoprofen possessed low capacity when compared with the unchanged drug, possibly by increasing the cytotoxic activity and increased absorption of the cells.

In this study we used morphological parameters to demonstrate the antiproliferative and antiangiogenic activity of ketoprofen. Immunohistochemical expression of intranuclear CDC47 protein has been widely studied, and is associated to the stimulation of gene duplication necessary for cell division (Nguyen et al., 2001; Dalton and Whitebread, 1995). CDC47 detects the number of cells that are cycling (predominantly G1 and S phases) (Homesley et $a l ., 2000)$. Our results demonstrate a decrease in CDC47 expression in animals treated with ketoprofen, and this may be a possible mechanism through which this chemotherapeutic agent controlled the proliferation of the Ehrlich tumor and consequent tumor development.

Angiogenesis is a key event in the growth of breast cancers, as in any other solid tumor (Folkman, 2003). Zúñiga et al. (2003) suggested that the effect of anti-angiogenic ketoprofen administered in low doses found in chorioallantoic membrane model may be due to its inhibitory action on $\mathrm{COX}$ isoforms that are associated with neovascularization.
Overall, our data indicate that the ketoprofen delays Ehrlich solid tumor growth in mice. The mechanisms of action by which the compound interferes in neoplastic growth seems to be associated with the inhibition of neoplastic proliferation and angiogenesis. This suggests the ketoprofen as a potentially important therapeutic option in oncology.

\section{ACKNOWLEDGEMENTS}

We are grateful to CAPES, CNPq and FAPEMIG for financial support.

\section{REFERENCES}

BACHMANN, J.; FRIESS, H.; MARTIGNONI, M.E. Molecular mechanisms and its clinical impact in cancer cachexia. Z. Gastroenterol, v.46, p.1384-1392, 2008.

BOSCO, J.L.F.; PALMER, J.R.; BOGGS, D.A. et al. Regular aspirin use and breast cancer risk in US Black women. Cancer Causes Control, v.22, p.1553-1561, 2011.

CHENG, K.C.; LI, Y.C.; YU, C.S. et al. Ketoprofen-inhibited $N$-acetyltransferase activity and gene expression in human colon tumor cells. Anticancer Research, v.26, p.1105-1112, 2006.

DALTON, S.; WHITBREAD, L. Cell cycleregulated nuclear import and export of CDC47, a protein essential for initiation of DNA replication in budding yeast. Proc. Natl. Acad. Sci., v.92, p.2514-2518, 1995.

FOLKMAN, J. Angiogenesis inhibitors: a new class of drugs. Cancer Biol. Ther., v.2, p.127133, 2003.

GILMAN, A.G.; GOODMAN, L.S.; RALL, T.W. et al. Goodman e Gilman: As bases farmacológicas da terapêutica, 10.ed. Rio de Janeiro: MacGraw- Hill, 2003. p.1647.

GRÖSCH, S.; MAIER, T.J.; SCHIFFMANN, S. et al. Cyclooxygenase-2 (COX-2) - Independent Anticarcinogenic. Effects of Selective COX-2 Inhibitors. J. Nat. Cancer Inst., v.85, p.10231031, 2006.

GUETA, I. ALTMAN, A.; SHOENFELD, Y. The effect of bloking TNF-alpha in patients with cancer-related cachexia and anorexia. Harefuah, v.149, p.512-514, 2010. 
HOMESLEY, L.; LEI, M.; KAWASAKI, Y.; SAWYER, S. et al. Mcm10 and the MCM2-7 complex interact to initiate DNA synthesis and to release replication factors from origins. Genes Dev., v.14, p.913-926, 2000.

HOSSAIN, M.A.; KIM, D.H.; KANG, Y.J. et al. Aspirin induces apoptosis in vitro and inhibits tumor growth of human hepatocellular carcinoma cells in a nude mouse xenograft model. Int. J. Oncol., v.4, p.1298-1304, 2011.

KAMEI, S.; SAKAYAMA, K.; TAMASHIRO, $\mathrm{S}$. et al. Ketoprofen in topical formalation decreases the matrix metalloproteinase-2 expression and pulmonary metastatic incidence in nude mice with osteosarcoma. J. Orthopaedic Res., v.27, p.909-915, 2008.

LI, Y.; BRASKY, T.M.; NIE, J. et al. Use of nonsteriodal anti-inflamatory drugs and survival following breast cancer diagnosis. Cancer Epidemiol. Biomarkers Prev., v.1, p.239-242, 2012.

MAEDA, Y.S.; CHUNG, TAKATSUKA, S. Tumor angiogenesis and tumour cell proliferation as prognostic indicators in gastric carcinoma. Br. J. Cancer, v.72, p.319-323, 1995.

MARJANOVIC', M.; ZORC, B.; PEJNOVIC', L. et al. Fenoprofen and ketoprofen amides as potential antitumor agents. Chem. Biol. Drug. Des., v.69, p.222-226, 2007.

NAKAMURA, K.; RADHAKRISHNAN, K.; WONG, Y.M. et al. Anti-inflamatory pharmacotherapy with Ketoprofen ameliorates experimental lymphatic vascular insufficiency in mice. PLoS ONE, v.4, e8380, 2009.

NGUYEN, V.Q.; CO, C.; LI, J.J. Cyclindependent kinases prevent DNA re-replication through multiple mechanisms. Nature, v.411, p.1068-1073, 2001.
O'BRIEN, J.; HANSEN, K.; BARKAN, D. et al. Non-steroidal anti-inflammatory drugs target the pro-tumorigenic extracellular matrix of the postpartum mammary gland. Int. J. Dev. Biol., v.55, p.745-755, 2011.

RAMOS, R.S.; VOLPATO, R.; LOPES, M.D. A contribuição da terapia com coxibes na oncologia de pequenos animais. Vet. e Zootec., v.4, p.461468, 2010.

RANG, H.P.; DALE, M.M.; RITTER, J.M. Farmacologia. 5.ed. Rio de Janeiro: Elsevier, 2004. p.904.

RAO, K.V.N.; DETRISAC, C.J.; STEELE, V.E. et al. Diffential activity of aspirin, ketoprofen and sulindac as cancer chemopreventive agents in the mouse urinary bladder. Carcinogenesis, v.17, p.1435-1438, 1996.

SANCHEZ, T.; MORENO, J.J. Ketoprofen S q enantiomer inhibits prostaglandin production and cellgrowth in 3 T6 fibroblast cultures. European J. Pharmacol., v.370. p.63-67, 1999.

SOUZA, C.M.; GAMBA C.O.; CAMPOS C.B. et al. Carboplatin delays mammary cancer 4T1 growth in mice. Pathology Research and Practice. v.209, p.24-29, 2013.

WARGOVICH, M.J.; JIMENEZ, A.; MCKEE, K. et al. Efficacy of potential chemopreventive agents on rat colon aberrant crypt formation and progression. Carcinogeneses, v.21, p.1149-1155, 2000.

ZERBINI, L.F.; TAMURA, R.E.; CORREA, R.G. et al. Combinatorial effect of non-steriodal anti-inflamatory drugs and NF-kB inhibitors in ovarian cancer therapy. PLoS ONE, v.6, e24285, 2011.

ZÚÑIGA, J.; FUENZALIDA, M.; GUERRERO, A. et al. Effects of steroidal and non steriodal drugs on the neovascularization response induced by tumoral TA3 supernatant on CAM from chick embryo. Biol. Res., v.36, p.233-240, 2003. 